\title{
16-17-VUOTIAIDEN SUOMALAISNUORTEN PUHEÄÄNEN KORKEUS
}

\author{
Ilkka Ketolainen, Turun yliopisto \\ Minna Laakso, Turun yliopisto \\ Susanna Simberg, Åbo Akademi, University of Oslo
}

\begin{abstract}
Puheäänen korkeuteen (FO) vaikuttavat anatomisten ja biologisten tekijöiden lisäksi erilaiset sosiokulttuuriset ja behavioraaliset käyttäytymismallit. Äänenkäytön kannalta epäoptimaaliset mallit voivat johtaa jopa äänihäiriöihin. Tutkimus selvitti, mikä on suomea äidinkielenään puhuvien 16-17-vuotiaiden nuorten puheäänen korkeus ääneen luettaessa ja spontaanipuheessa. Lisäksi tutkittavilta mitattiin lukunopeus, FO vokaalifonaatiossa, ja heiltä kerättiin äänenkorkeuden itsearvio. Tuloksia verrattiin Aino Sallinen-Kuparisen (1985) tutkimukseen, jossa havaittiin puhujien sukupuolen ja koulutustaustan vaikuttavan FO:an.

Suomalaisnuorten puhekäyttäytyminen näyttäisi muuttuneen 30 vuodessa: Sallinen-Kuparisen (1985) tutkimuksessa ammattikoulutytöt puhuivat lukiotyttöjä korkeammalta ja sukupuolten välillä esiintyi eri puhetehtävissä eri strategioita, mutta tässä tutkimuksessa koulutustausta tai sukupuoli ei ollut yhteydessä äänenkorkeuden säätelyyn puheessa. Tyttöjen F0 oli luennassa 216 $\mathrm{Hz}$ ja spontaanipuheessa $213 \mathrm{~Hz}$. Poikien FO oli kansainvälisesti verrattuna matala: lukunäytteissä $101 \mathrm{~Hz}$ ja spontaanipuheessa $97 \mathrm{~Hz}$. Mahdollisesti poikiin vaikuttaa täysi-ikäisyyden kynnyksellä sosiaalinen normi, joka arvostaa matalan puheäänen käyttöä. Matalaa puheääntä suosittiin myös itsearvioissa: valtaosa tutkittavista arvioi puhekorkeutensa keskivertoa matalammaksi.
\end{abstract}

Avainsanat: F0, puheäänen korkeus, sosiaaliset normit

\section{JOHDANTO}

Puheäänen perustaajuus (F0, perussävel) on kuultava äänen korkeustaso, jonka yksikkö hertsi $(\mathrm{Hz})$ kertoo äänihuulien värähtelymäärän sekunnissa (mm. Seikel, King \& Drumright, 2005). Äänenkorkeuteen vaikuttavat keskeisimmin sukupuoli, ikä sekä mahdolliset sairaudet. Puheäänen korkeutta on tutkittu pääosin Euroopassa ja Pohjois-Amerikassa,

Kirjoittajan yhteystiedot:

Ilkka Ketolainen

ilkka.ketolainen@turku.fi ja F0:n viitearvoiksi on saatu miehille noin $100-125 \mathrm{~Hz}$ ja naisilla noin $200-220 \mathrm{~Hz}$ (mm. Bless, Glaze, Biever-Lowery, Campos \& Peppard, 1993; Hollien \& Jackson, 1973; Laukkanen \& Leino, 1999; Murry, Brown \& Morris, 1995; Simpson, 2009). Ikä vaikuttaa puheäänen korkeuteen miehillä ja naisilla eri tavoin. Miehillä suurin muutos tapahtuu murrosiässä, minkä jälkeen ääni mataloituu noin 35-vuotiaaseen asti, kunnes noin 55-vuotiaana F0 alkaa taas nousta (Hollien \& Ship, 1972; Kitzing, 1979; PegoraroKrook, 1988). Naisilla F0 pysyy murrosiän jälkeen melko tasaisena vaihdevuosiin asti, minkä jälkeen se alkaa laskea, ja madaltuu 
keskimäärin $15 \mathrm{~Hz}$ noin 70 ikävuoteen mennessä (Chevrie-Muller, Salomon \& Ferrey, 1971; Kitzing, 1979; Pegoraro-Krook, 1988; Stoicheff, 1981). Anatomisten ja biologisten muuttujien perusteella puhujalle muodostuu yksilöllinen ääniala, jonka sisällä äänenkorkeutta on mahdollista muutella fysiologisesti.

Puheäänen keskiarvoinen korkeus ja korkeusvaihtelut ilmentävät yhteisössä vallitsevia prestiisejä, suosittuja piirteitä, jotka ovat pitkälti tiedostamattomia, ja ne heijastavat muun muassa kielelle ominaista puhetapaa, sukupuolinormeja, sosioekonomista taustaa ja vallankäyttöä (mm. Dolson, 1994; Jones, Feinberg, DeBruine, Little \& Vukovic, 2010; Scherer \& Giles 1979; Valo, 1994; van Bezooijen, 1995). Valo (1994) on määritellyt äänistereotypioiksi viestintäyhteisössä vallitsevia kulttuurisidonnaisia oletuksia siitä, millaisia äänenkäyttötapoja on tietynlaisilla tai tiettyihin ryhmiin kuuluvilla ihmisillä. Esimerkiksi monissa kulttuureissa stereotyyppisen maskuliiniseen puheeseen kuuluu matala F0, harvat ja kapealla äänialalla toteutetut korkeusvaihtelut, mahdollisesti karhea äänenlaatu sekä maltillinen puhenopeus (Brend, 1975; Elert, 1977; Fichtelius, Johansson \& Nordin, 1980; Gilmore, Guidera, Hutchins \& van Steenbrugge, 1992; Lass, Hughes, Bowyer, Waters \& Bourne, 1976). Vastaavasti stereotyyppisen feminiiniselle puheelle pidetään tyypillisenä muun muassa korkeusvaihteluita, äänen vuotoisuutta sekä nousevaa intonaatiota toteavissa lauseissa (Avery \& Liss, 1996; Lakoff, 1973; van Bezooijen, 1995; van Borsel, Janssens \& de Bodt, 2009).

\section{Puheä̈nen korkeuteen vaikuttavat sosiokulttuuriset ja behavioraaliset tekijät}

Puheäänen korkeus on oletettavasti jokseenkin kieli- ja kulttuurisidonnaista ( $\mathrm{mm}$. Dolson, 1994). Vertailtaessa tutkimustietoa eri maista havaitaan, että esimerkiksi puolaa, arabiaa ja bulgariaa puhuvat miehet näyttäisivät käyttävän tyypillisiä viitearvoja (100-120 $\mathrm{Hz}$ ) korkeampaa puheääntä, kun taas ruotsia, englantia, suomea ja saksaa puhutaan matalalta (taulukko 1).

Tyypillistä naisten viitearvoa (200-220 $\mathrm{Hz}$ ) korkeampaa ääntä käyttävät esimerkiksi arabian, bulgarian ja puolan puhujat. Lisäksi Japanissa on kulttuurisesti odotettua, että nainen puhuu korkealla äänellä, ja japanilaisten naisten puheäänestä on saatu eri tutkimuksissa viitearvoiksi 225-239 Hz (mm. Ohara, 1992; van Bezooijen, 1995; Yamazawa \& Hollien, 1992). Viitearvoja matalampi naisääni puolestaan löytyy esimerkiksi ruotsin, englannin, flaamin, portugalin sekä suomen puhujilta. Suomalaisaineistoa edustaa Leinon ym. (2008) tutkimus, jossa suomalaiset 23-26-vuotiaat yliopisto-opiskelijat lukivat ääneen kaksi noin minuutin mittaista tekstiä.

Puheäänen korkeudella on mahdollista korostaa sukupuolieroja, mikä näyttäisi olevan universaalisti suosittu käyttäytymismalli. Sachsin ym. (1973) mukaan miesten ja naisten äänten akustiset erot ovat suuremmat kuin minkä anatominen ero selittäisi. Korkea naisääni ja matala miesääni näyttävät olevan monessa kulttuurissa prestiisi. Sukupuolirooleihin ja sukupuolittuneeseen puhetapaan sosiaalistutaan jo lapsena. Poikien ja tyttöjen ääntöelimistössä ei ole merkittäviä anatomisia eroja ennen murrosikää (mm. Lee, Hewlett \& Nairn, 1995), ja siksi tyttöjen ja poikien puhekorkeus vaihtelee samalla taajuusalueella. Esimerkiksi tyttö- ja poikakuoroja on vaikea erottaa toisistaan pelkän lauluäänen perusteella (Welch \& Howard, 2002; White, 1999). Samankaltaisesta ääntöelimistöstä huolimatta lapsen sukupuoli kuitenkin erotetaan kuulonvaraisesti todennäköisemmin kuin vain arvaamalla (mm. Sachs, Lieberman \& Erikson, 1973). 
TAULUKKO 1. Miesten ja naisten puheäänen korkeus eri kielissä lukutehtävässä tai *spontaanipuheessa.

\begin{tabular}{|c|c|c|c|c|c|}
\hline \multirow[t]{2}{*}{ Tutkimus } & \multirow[t]{2}{*}{ Kieli } & \multicolumn{2}{|c|}{$\bar{x} F 0(H z)$} & \multirow[t]{2}{*}{$\mathrm{N}(\hat{\partial} / q)$} & \multirow[t]{2}{*}{ Ikä } \\
\hline & & Miehet & Naiset & & \\
\hline Fitch \& Holbrook (1970) & $\begin{array}{l}\text { englanti } \\
\text { (Yhdysvallat) }\end{array}$ & 117 & 217 & $\begin{array}{l}200 \\
(100 / 100)\end{array}$ & $17-25$ \\
\hline Majewski ym. (1972) & puola & 138 & & 103 & $17-28$ \\
\hline \multirow[t]{2}{*}{ Hollien \& Jackson (1973) } & $\begin{array}{l}\text { englanti } \\
\text { (Yhdysvallat) }\end{array}$ & 129 & & 157 & $17-25$ \\
\hline & & $123^{*}$ & & 157 & $17-25$ \\
\hline Pegoraro-Krook (1988) & ruotsi & 112 & 196 & $42(7 / 35)$ & $20-29$ \\
\hline Britto \& Doyle (1990) & englanti (Kanada) & 115 & 199 & $40(20 / 20)$ & $24-25$ \\
\hline Brown ym. (1991) & $\begin{array}{l}\text { englanti } \\
\text { (Yhdysvallat) }\end{array}$ & 118 & 192 & $35(15 / 20)$ & $20-35$ \\
\hline $\begin{array}{l}\text { Pegoraro-Krook \& Castro } \\
\text { (1994) }\end{array}$ & $\begin{array}{l}\text { portugali } \\
\text { (Brasilia) }\end{array}$ & 135 & & 150 & $17-30$ \\
\hline van Bezooijen (1995) & $\begin{array}{l}\text { flaami } \\
\text { (Alankomaat) } \\
\end{array}$ & & 191 & 20 & $20-30$ \\
\hline $\begin{array}{r}\text { Pemberton ym. (1998) } \\
\text { v. } 1943\end{array}$ & $\begin{array}{l}\text { englanti } \\
\text { (Australia) }\end{array}$ & & 229 & 28 & $18-25$ \\
\hline v. 1993 & & & 206 & 28 & $18-25$ \\
\hline \multirow[t]{2}{*}{$\begin{array}{l}\text { Guimarães \& Abberton } \\
\text { (2005) }\end{array}$} & $\begin{array}{l}\text { portugali } \\
\text { (Portugali) }\end{array}$ & 116 & 197 & $33(10 / 23)$ & $19-40$ \\
\hline & & $113^{*}$ & $190^{*}$ & $33(10 / 23)$ & $19-40$ \\
\hline Leino ym. (2008) & suomi & 110 & 194 & $252(63 / 189)$ & $23-26$ \\
\hline Natour \& Wingate (2008) & $\begin{array}{l}\text { arabia } \\
\text { (Jordania) }\end{array}$ & $138^{*}$ & $231^{*}$ & $\begin{array}{l}200 \\
(100 / 100)\end{array}$ & $18-24$ \\
\hline Ma \& Love (2010) & englanti (Australia) & 114 & 197 & $23(11 / 12)$ & $20-32$ \\
\hline da Silva ym. (2011) & portugali (Brasilia) & & 203 & 30 & $20-35$ \\
\hline \multirow[t]{4}{*}{ Andreeva ym. (2014) } & bulgaria & 160 & 272 & $60(30 / 30)$ & $n / a^{* *}$ \\
\hline & puola & 163 & 266 & $48(24 / 24)$ & $n / a^{* *}$ \\
\hline & saksa & 118 & 210 & $60(30 / 30)$ & $\mathrm{n} / \mathrm{a}^{* *}$ \\
\hline & $\begin{array}{l}\text { englanti } \\
\text { (Iso-Britannia) }\end{array}$ & 128 & 217 & $60(30 / 30)$ & $n / a^{* *}$ \\
\hline
\end{tabular}

** ei saatavilla (not available)

Joskus äänenkorkeuden avulla ilmaistaan omaa asemaa tai sosioekonomista taustaa tietyssä yhteisössä. Scherer \& Giles (1979) kirjoittavat, että Britanniassa korkea puheääni liitetään korkeaan sosiaaliseen asemaan.
Toisaalta äänenkorkeudella voidaan ilmaista myös valtaa ja auktoriteettia. Kuulijaraatitutkimuksessa sekä mies- että naisraati tulkitsi matalat ääninäytteet autoritaarisemmiksi kuin korkeat ääninäytteet (Jones ym. 2010). 
Ohalan (1994) frekvenssikooditeorian mukaan korkea taajuus yhdistetään pieneen äänilähteeseen, minkä vuoksi se tulkitaan alistuvaksi ja vähemmän uhkaavaksi. Vastaavasti suuri lähde tuottaa matalataajuisemman äänen, joka viestii uhkaavuutta ja ylemmyyttä. Tätä kutsutaan myös äänisymbolismiksi, ja teorian mukaan sitä esiintyy sekä ihmisillä että eläimillä. Matala ääni tulkitaan siis primitiivisesti hallitsevammaksi ja korkea ääni alistuvammaksi.

Mielenkiintoinen ilmiö viime vuosikymmeniltä on naisten puheäänen madaltuminen (mm. Leino, Laukkanen, Kättö, Mäki \& Ilomäki, 1998; Muranaka, 1996; Okamoto, 1995; Pemberton, McCormack \& Russell, 1998), ja se oletettavasti liittyy yhteiskunnalliseen muutokseen ja tasa-arvon lisääntymiseen sukupuolien välillä. Naisen ääni osana julkisesta puhetta on vähitellen vakiintunut politiikassa ja medioissa. Sekä Cooper (1984) että Boone (1991) ovat olettaneet, että naisten puheäänen madaltuminen viestii halusta välittää itsestä vakavasti otettava tai kypsä mielikuva. Puheäänen madaltuminen ei liene pelkästään tiedostamatonta käyttäytymistä, koska esimerkiksi julkisessa puheessa siihen liittyy vakuuttavuuden tavoittelu.

Edellisten tekijöiden lisäksi puheääneen vaikuttavat myös behavioraaliset tekijät. Yksilö voi tietoisesti tai tiedostamatta muokata äänellistä käyttäytymistään ryhmän normien mukaiseksi, pyrkimyksenä liittyä ryhmään ja hakea sen jäsenten hyväksyntää (esim. Cooper, 1973; Martin, Klingholz \& Eicher, 2012; Neumann \& Welzel, 2003; Rousey \& Moriarty, 1965; van Riper, 1972). Cooper (1973) määrittelee ääni-identiteetin (eng. vocal image) olevan äänenkäyttötapa, josta yksilö pitää tai jota hän inhoaa, johon hän samaistuu tai johon hän ei halua samaistua. Tietynlaisen puheäänen hyväksyttävyyteen vaikuttavat esimerkiksi taustakulttuuri, roolimallit, media ja vertaisryhmän paine. Yksilö saattaa tavoitella omassa puheessaan ihannoimansa laulajan, näyttelijän tai poliitikon äänenkäyttöä, tai muuta yhteisössä hyväksyttyä äänenkäyttötapaa (Rousey \& Moriarty, 1965; van Riper, 1972). Puheäänen korkeudella yksilö voi tavoitella tiettyä ääni-identiteettiä, joka heijastaa sosiokulttuurisesti haluttuja ominaisuuksia ja sosiaalisia rooleja (Ohara, 1992).

Tietynlaisen ääni-identiteetin toteuttaminen voi johtaa epäoptimaaliseen puhekorkeuteen. Pitkittynyt puhuminen epäsopivalta korkeudelta, liian voimakkaasti tai pakotetun karheasti kasvattaa äänihuuliin kohdistuvaa kuormitusta, voi aiheuttaa äänen väsymistä, vaikeuttaa matalimpien taajuuksien tuottamista sekä lisää merkittävästi riskiä äänihuulten kudosvaurioihin ja äänihäiriön kehittymiselle (esim. Jiang \& Titze, 1994; Stemple, Glaze \& Klaben, 2010). Esimerkiksi jatkuva normaalia matalampi puhekorkeus voi olla vahingollista äänelle ja aiheuttaa jopa äänihuulikyhmyjä tai granuloomia (mm. Aronson, 1973; Brodnitz, 1965; Tuomi \& Fisher, 1979).

\section{Sallinen-Kuparisen (1985) tutkimus suomalaisten nuorten pubeäänen korkeudesta, tekstilajistaja pubetilanteesta}

Aino Sallinen-Kuparisen tutkimuksessa vuodelta 1985 on viitteitä siitä, että lukion ja ammattikoulun oppilaat käyttävät puhuessaan äänenkorkeutta eri tavalla ja että tekstilaji ja puhetilanne vaikuttavat äänenkorkeuden keskiarvoon. Tutkimuksessa äänitettiin 16-17-vuotiaiden suomalaisnuorten puhetta kolmessa lukutehtävässä ja kahdessa spontaanipuhetehtävässä. Tutkittavat olivat pääosin 16-vuotiaita ammattikoululaisia ja lukiolaisia, joista puolet oli tyttöjä ja puolet poikia $(\mathrm{N}=60)$. Ääneen luettavat tekstit olivat uutinen, mielipidekirjoitus ja lyhyt tarina (Sallinen-Kuparinen, 1990). Spontaa- 
nipuhetehtävässä tutkittavat kuvailivat kahta sarjakuvaa niin kuin he kertoisivat siitä luokkatoverilleen.

Sallinen-Kuparisen (1985) tutkimuksessa kävi ilmi, että sukupuoli vaikutti oppilaiden äänenkäyttöön puheessa: tytöt käyttivät noin puoli sävelaskelta $(7 \mathrm{~Hz})$ korkeampaa puheääntä lukutehtävässä kuin spontaanipuheessa, kun taas pojilla F0 pysyi suhteellisen tasaisena eri puhetilanteissa. Syyksi tutkija määritteli sosiaalisen normin, joka ei rohkaise poikia värikkääseen äänelliseen ilmaisuun. Myös koulutustausta oli erotteleva tekijä tyttöjen otoksissa: Ammattikoulutytöt puhuivat korkeammalta kuin lukiotytöt tekstiä luettaessa ja spontaanipuheessa. Poikien äänenkorkeudessa ei esiintynyt tilastollisesti merkitsevää eroa. Oppilaiden F0 oli kytköksissä myös tekstien muodollisuuteen ja tunnesisältöön: uutisessa ja mielipidekirjoituksessa F0-arvot olivat matalammat kuin tarinassa. Tekstityyppinä tarina oli helppolukuisin, sillä siinä oli suurin tunnesisältö, lauseet lyhyitä ja sanasto arkipäiväistä, ja koehenkilöt alleviivasivat tunnevihjeitä nostamalla äänenkorkeuttaan. Poikkeuksena olivat kuitenkin ammattikoulupojat, jotka lukivat tarinan emotionaalisesti latautuneimmat kohdat madaltaen perustaajuutta.

\section{Tutkimuksen tarkoitus ja tutkimuskysymykset}

Tässä tutkimuksessa selvitettiin, mikä on suomea äidinkielenään puhuvien 16-17-vuotiaiden nuorten puheäänen korkeus. Lisäksi tutkittiin, onko pojilla ja tytöillä erilaisia strategioita äänenkorkeutta säädellessään, ja onko puhujan koulutustaustalla vaikutusta puheäänen korkeuteen. Tämä työ on uusintatutkimus Sallinen-Kuparisen (1985) työstä (jatkossa alkuperäistutkimus), joskin alkuperäistä tutkimusasetelmaa täydennettiin kolmella uudella tehtävällä. Uusintatutkimuksessa etsitiin vastauksia samoihin kysymyksiin kuin alkuperäistutkimuksessa 30 vuotta sitten: miten koulutustausta, tekstilaji, puhetilanne sekä puhujan sukupuoli vaikuttavat puheen perustaajuuteen.

Tämän ikäryhmän puheääntä on tutkittu maailmanlaajuisesti varsin vähän, eikä siitä ole olemassa ajantasaisia äänenkorkeuden viitearvoja. Sallinen-Kuparisen havainnot vuodelta 1985 saatiin verrattain pienestä otoksesta, ja suomalainen yhteiskunta on muuttunut 30 vuodessa, joten on mahdollista, että sukupuoli tai koulutustausta vaikuttaa puheäänessä nykyään eri tavalla. Lähimmät viitearvot suomalaisväestöstä ovat Leinon ym. julkaisusta vuodelta 2008, jonka aineisto on kerätty osin jo 1990-luvulta 23-26-vuotiailta yliopistoopiskelijoilta (A-M. Laukkanen, henkilökohtainen tiedonanto, 24.1.2017). Normitettu vertailuaineisto puheäänen korkeudesta olisi tärkeää siksi, että puheterapeuttisissa arvioissa voitaisiin ottaa kantaa siihen, onko asiakkaan F0 poikkeava.

Alkuperäistutkimuksen näkökulma oli viestinnällinen, mutta uusintatutkimus tarkastelee puheäänen korkeutta logopedian näkökulmasta osana ääniergonomiaa. Aihetta käsitellään poikkitieteellisesti mm. sosiaali- ja viestintätieteiden näkökulmasta, sillä puheäänen korkeuden tehtävä on myös välittää monia sosiokulttuurisia viestejä.

\section{AINEISTO JA MENETELMÄT}

\section{Tutkittavat}

Tutkimukseen osallistujat olivat 16-17-vuotiaita nuoria, joiden äidinkieli oli suomi $(\mathrm{N}=80)$. Tutkittavat jakautuivat neljään samankokoiseen otokseen $(n=20)$ : lukiopojat, ammattikoulupojat, lukiotytöt ja ammattikoulutytöt. Alkuperäistutkimukseen osallistui 60 tutkittavaa, jotka jakautuivat vastaaviin otoksiin $(\mathrm{n}=15)$. Tässä tutkimuksessa otoskokoa kasvatettiin, koska isompi aineisto edus- 
taa paremmin populaatiota. Tutkimukseen valittiin täysi-ikäisyyden kynnyksellä olevia oppilaita, koska äänenmurros oli tuolloin jo oletettavasti ohi ja heidän äänensä oli aikuisen kaltainen. Tutkittavat olivat taustaltaan vastaavat kuin alkuperäistutkimuksessa.

Ikäjakauma oli 16;0-17;11 vuotta, mutta iän keskiarvo oli kaikissa otoksissa 17 vuotta, sillä valtaosa kävi lukion tai ammattikoulun toista vuosikurssia. Puhenäytteet kerättiin kahdesta lukiosta ja kolmesta ammattikoulun koulutalosta, jotta aineistoon tulisi usean eri alan oppilaita. Aineiston ammattikoululaiset edustavat seitsemää koulutusalaa.

Taulukkoon 2 on koottu esitietolomakkeiden perusteella tutkittavien taustatietoja.

TAULUKKO 2. Tutkittavien ( $\mathrm{N}=80)$ taustatietoja.

\begin{tabular}{|l|c|l|c|c|c|c|}
\hline & N & $\begin{array}{l}\text { Lukiovuosi / } \\
\text { ammattikoulun koulutusala }\end{array}$ & Tupakointi & $\begin{array}{c}\text { Allergiat } \\
\text { tai astma }\end{array}$ & $\begin{array}{c}\text { Flunssa- } \\
\text { oireita }\end{array}$ & $\begin{array}{c}\text { Käynyt puhe- } \\
\text { terapeutilla }\end{array}$ \\
\hline Lukiopojat & $20 \begin{array}{l}\text { I luokka: 3 } \\
\text { II luokka: 17 }\end{array}$ & 2 & 7 & 1 & 3 \\
\hline $\begin{array}{l}\text { Lukiotytöt } \\
\text { Ammatti- } \\
\text { koulupojat }\end{array}$ & $20 \begin{array}{l}\text { Il luokka: } 16 \\
\text { III luokka: } 1\end{array}$ & $\begin{array}{l}\text { Sähkö- ja } \\
\text { automaatiotekniikka: 13 } \\
\text { Autoala: 6 } \\
\text { Rakennusala: 1 }\end{array}$ & 3 & 3 & 1 & 3 \\
\hline $\begin{array}{l}\text { Ammatti- } \\
\text { koulutytöt }\end{array}$ & $\begin{array}{l}\text { Kauneudenhoitoala: 7 } \\
\text { Hotelli-, ravintola- ja } \\
\text { catering-ala: 7 } \\
\text { Hiusala: 5 } \\
\text { Autoala: 1 }\end{array}$ & 4 & 7 & 5 & 6 \\
\hline
\end{tabular}

Esitietolomakkeen mukaan 18 tutkittavaa (6 lukiolaista, 12 ammattikoululaista) oli joskus käynyt puheterapeutilla. Käyntisyynä olivat lähinnä artikulaatiovirheet, joten heitä ei ollut syytä sulkea pois tutkimuksesta. Lukiolaisista 4 ja ammattikoululaisista 7 tupakoi. Tutkittavista 24 raportoi allergiasta tai astmasta: pelkästään allergioita oli 15 tutkittavalla (n. $19 \%$ ), pelkästään astmaa 5 tutkittavalla (n. 6\%) ja molempia 4 tutkittavalla (n. $5 \%$ ). Aineiston laadun varmistamiseksi puhenäytteitä kerättiin kaikkiaan 90 oppilaalta, eli kuhunkin otokseen haastateltiin muutama ylimääräinen henkilö. Analyysin ulkopuolelle rajattiin lopulta 6 poikaa (3 lukiosta, 3 ammattikoulusta) ja 4 tyttöä (3 lukiosta, 1 ammattikoulusta), koska aineiston keräämisen edetessä oppilaiden puhenäytteistä havaittiin poissulkukriteereitä, joita ei käynyt ilmi esitietolomakkeita täytettäessä: epänormaali äänenlaatu, flunssan vaikutus ääneen ja poikkeava äänenkorkeus (ero muuhun aineistoon yli 2SD). 4 tutkittavalla jompikumpi vanhempi puhui äidinkielenään jotain muuta kuin suomea, mutta tämä ei rajannut oppilaita tutkimuksen ulkopuolelle, sillä he olivat puhuneet koko ikänsä kotona vain suomea ja määrittelivät itsensä yksikielisiksi. 
Tutkimuslupa lukiolaisten ja ammattikoululaisten haastatteluun myönnettiin Turun Sivistystoimialasta lukioiden osalta 23.9.2015 ja ammattikoulujen osalta 3.11.2015 Tutkimukseen osallistuminen oli vapaaehtoista ja anonyymia. Oppilaita informoitiin tutkimuksen kulusta sekä suullisesti että kirjallisesti. Tuloksia tai ääninäytteitä ei ole mahdollista jäljittää kehenkään yksittäiseen puhujaan, eivätkä ääninäytteet ole julkisesti saatavia. Suostumuksellaan oppilaat antoivat luvan tallennetun materiaalin säilyttämiseen jatkotutkimusta varten. Turun yliopiston eettistä toimikuntaa konsultoitiin tutkimusasetelman osalta ennen aineiston keruuta. Koska kyseessä oli ei-lääketieteellinen tutkimus ja tutkittavat olivat yli 15-vuotiaita, saivat oppilaat allekirjoittaa suostumuslomakkeen itse ilman vanhempien erillistä lupaa.

\section{Tutkimusmenetelmät}

Aineisto kerättiin loka-joulukuussa 2015 kunkin kouluyksikön tiloissa normaalin koulutyön ohessa. Puhenäytteet äänitettiin erilaisissa koulutiloissa: luokkahuoneessa, kansliassa, neuvotteluhuoneessa, kopiohuoneessa, varastossa, nuorisotilassa ja väestönsuojassa. Koska käytettävissä ei ollut studiota, vaan tilan sisällä tai ulkopuolella saattoi olla hälynlähteitä (esim. ilmastointi, lämpöpatterit, viereisten tilojen tai käytävän taustahäly), äänitettiin puhenäytteet korvamikrofonilla, jonka etäisyys suusta oli $5 \mathrm{~cm}$. Reliabiliteetin vuoksi puhenäytteet äänitettiin kahdella tallentimella: Praat-puheanalyysiohjelmalla (Boersma \& Weenink, 2015) sekä kaksikanavaisella digitaalisella M-AUDIO Microtrack II -tallentimella. Kummankin laitteiston mikrofonit olivat kiinnitettynä samaan varteen samalle etäisyydelle suusta.

Tutkimusasetelma ja osallistujien suullinen ohjeistus oli joka kerta samanlainen: tutkija esittäytyi luokalle oppitunnin alussa ja kertoi tutkivansa 16-17-vuotiaiden puhetta, jota äänitetään korvamikrofonin avulla eri tehtävissä yhteensä noin 5 minuuttia, ja että tutkimukseen osallistuminen kestää kaikkiaan noin 1520 minuuttia. Vapaaehtoiset oppilaat täyttivät luokassa esitietolomakkeen, jossa kartoitettiin demografisia tietoja, äänenkäyttöhistoriaa sekä äänenkäytön riskitekijöitä. Sen jälkeen heidät otettiin yksitellen vastaan tutkimushuoneessa, jossa esitietolomake käytiin läpi yhdessä tutkijan kanssa. Mikäli lomakkeesta kävi ilmi poissulkukriteereitä (kaksikielisyys, lukihäiriö, äänenmurroksen keskeneräisyys, äänihäiriö, transsukupuolisuus, hengitystieinfektio) tai jos haastattelun aikana tutkija havaitsi tutkittavan äänen olevan epäterve, ei puhenäytteitä äänitetty. Oppilaita tiedotettiin tutkimuksen kulusta sekä suullisesti että kirjallisesti, ja he allekirjoittivat suostumuslomakkeen ennen puhenäytteiden äänitystä.

Jokaiselta tutkittavalta kerättiin analyysia varten seitsemän lyhyttä puhenäytettä: kolme tekstinluentaa, vokaalifonaatio sekä kolme spontaanipuhenäytettä (Ketolainen, 2016). Luettavat tekstinäytteet olivat uutinen, mielipidekirjoitus ja satu, ja niiden pituus oli 146164 sanaa (1115-1327 merkkiä). Teksteiksi valittiin sellaiset, joiden tyyli ja kielellinen taso vastaisivat alkuperäistutkimuksen tekstejä. Oppilaat saivat silmäillä tekstiä hetken aikaa ennen kuin äänitys aloitettiin. Tutkittavat ohjeistettiin lukemaan tekstit ääneen keskeytyksettä alusta loppuun tekstilajille ominaisella tyylillä. Vokaalifonaatiossa tutkittavat äänsivät vokaalin /a/ viisi kertaa noin viiden sekunnin ajan normaalilla voimakkuudella ja itse valitsemaltaan korkeudelta. Tätä testiosiota ei ollut alkuperäisessä tutkimusasetelmassa, mutta se päätettiin lisätä nopeana keinona saada lisäinformaatiota F0:sta. Pitkän vokaalifonaation avulla oli tarkoitus selvittää, eroaako se puhenäytteiden F0:sta. Logopedisestä näkökulmasta vokaalifonaatio on käyttökelpoinen rinnakkaismittari, sillä se 
paljastaa puhujan äänen korkeuden nopeasti, ja sitä käytetään yleisesti akustisessa analyysissa (mm. Kempster, Gerratt, Verdolini Abbott, Barkmeier-Kramer \& Hillman, 2009; Consensus auditory-perceptual evaluation of voice (CAPE-V), 2016). Puheterapeutit käyttävät vokaalifonaatiota osana äänenlaadun tutkimista, ja vokaaliäännössä puhuja yleensä tuottaa spontaanisti tavallista puhetta korkeamman äänen (mm. Kempster ym., 2009; Murry ym., 1995).

Spontaanipuhenäytteissä oppilas kuvaili tutkijalle kahta sarjakuvaa, joissa ei ollut puhekuplia. Ensimmäinen sarjakuva oli 8 ruudun mittainen tarina Karvisesta, joka seikkailee puutarhassa. Toinen sarjakuva oli 12 ruudun mittainen mustavalkoinen ketjutarina koirasta, joka juoksee isäntänsä luo selvityen eri esteistä. Tutkittavat saivat silmäillä sarjakuvia hetken aikaa ennen äänityksen aloittamista. Spontaanipuhenäytteenä tutkittavat nimesivät myös kolme asiaa, mitä he tekisivät, jos voittaisivat miljoona euroa. Avoin kysymys lisättiin alkuperäiseen tutkimusasetelmaan, jotta voitaisiin verrata, eroaako se tehtävätyyppinä kuvasta kertomisesta. Kolmantena uusintatutkimukseen lisättynä tehtävänä oppilaita pyydettiin arvioimaan omaa puheäänen korkeutta VAS-janalla (eng. visual analogue scale, ks. esim. Wewers \& Lowe, 1990), jossa 100 mm:n mittaiselle janalle merkitään viiva, joka kuvaa koehenkilön sijoittumista jatkumolle kahden annetun ääripään välissä. Tarkoituksena oli kartoittaa koehenkilöiden mielikuvia omasta puheäänestä ja selvittää, korreloivatko itsearviot mitattujen arvojen kanssa. Lopuksi koehenkilöiltä pyydettiin lupa äänitetyn materiaalin arkistoimiseen.

Tutkimusmenetelmät ja -asetelma olivat vastaavat kuin 30 vuotta sitten, mutta täysin identtistä toisintoa ei ollut mahdollista tehdä, sillä alkuperäiset tekstit olisivat olleet nykypäivän oppilaille vieraannuttavia eikä alkuperäinen mittauslaitteisto ollut enää käytettävissä.

\section{Aineiston käsittely ja analyysi}

Tietokoneelle tallennettu aineisto siirrettiin Praat-puheenkäsittelyohjelmaan (Boersma \& Weenink, 2015), jolla aineisto analysoitiin. Tutkittavien puheessa esiintyi erittäin runsaasti narinaa, mikä oli otettava huomioon näytteitä analysoitaessa: pojilla sitä ilmeni noin 60 \%:lla ja tytöillä yhtä lukuun ottamatta kaikilla. Narina piti suodattaa pois, sillä etenkin naisilla se vaikuttaa puheen F0:an (Plexico \& Sandage, 2017). Matalampi narinataajuus alentaa F0:n keskiarvoa, joka ei vastaa kuultavaa puheäänen korkeutta. Siksi näytteistä analysoitiin vain puheäänen taajuusväli. Taajuusväliksi haarukoitiin aineiston tarkan läpikäynnin sekä kirjallisuuden viitearvojen perusteella pojille 55-275 Hz ja tytöille 130-415 Hz (mm. Bless ym., 1993; Hollien \& Jackson, 1973; Laukkanen \& Leino, 1999; Murry ym., 1995; Simpson, 2009). Kuten alkuperäistutkimuksessa, puhenäytteistä mitattiin aineiston kuvailevina tunnuslukuina puhekorkeuden keskiarvo, keskihajonta, keskivirhe sekä lukunäytteisiin käytetty aika.

Mitatut arvot analysoitiin tilastollisesti SPSS-ohjelmiston versiolla 19 (eng. Statistical Product and Service Solutions, IBM, Armonk, NY). Vertailtavina muuttujina käytettiin puhekontekstia (tekstin lukeminen ja spontaanipuhe), lukemiseen käytettyä aikaa sekä koehenkilöiden koulutustaustaa ja sukupuolta. Puhekontekstin vaikutuksen selvittämiseksi laskettiin kussakin otoksessa kaikista kolmesta lukunäytteestä yhteinen keskiarvo, jota verrattiin spontaanipuhenäytteiden keskiarvoon. Lisäksi puhenäytteiden keskiarvoja verrattiin vokaalifonaation keskiarvoon. Koska otoskoko oli 20, normaalijakaumaoletus testattiin Shapiro-Wilk-testillä. Otosten vertailussa tilastollinen merkitsevyys määriteltiin Studentin t-testillä aina silloin, kun aineisto noudatti normaalijakaumaa. Mikäli aineisto ei noudattanut normaalijakaumaa, käytettiin 
epäparametrisiä Mann-Whitneyn U-testiä sekä Wilcoxonin merkittyjen sijalukujen testiä. Tilastollisen merkitsevyyden raja-arvona pidettiin $\mathrm{p}<0,05$. Tulokset esitetään samassa muodossa kuin alkuperäistutkimuksessa.

\section{TULOKSET}

Kaikissa testiosioissa tyttöjen puhekorkeuden keskihajonta oli suurempi kuin poikien (kuvio 1). Tämä ei kuitenkaan tarkoita automaat- tisesti, että tyttöjen otokset olisivat heterogeenisempiä kuin poikien otokset, sillä hertsiasteikko kasvaa epälineaarisesti. Esimerkiksi subjektiivisesti aistittava yhden sävelaskeleen korkeusero miesäänen puhumana $100 \mathrm{~Hz}$ korkeudelta on 11-12 Hz, kun naisäänen puhumana $215 \mathrm{~Hz}$ korkeudelta sama korkeusero on jo $23-27 \mathrm{~Hz}$.

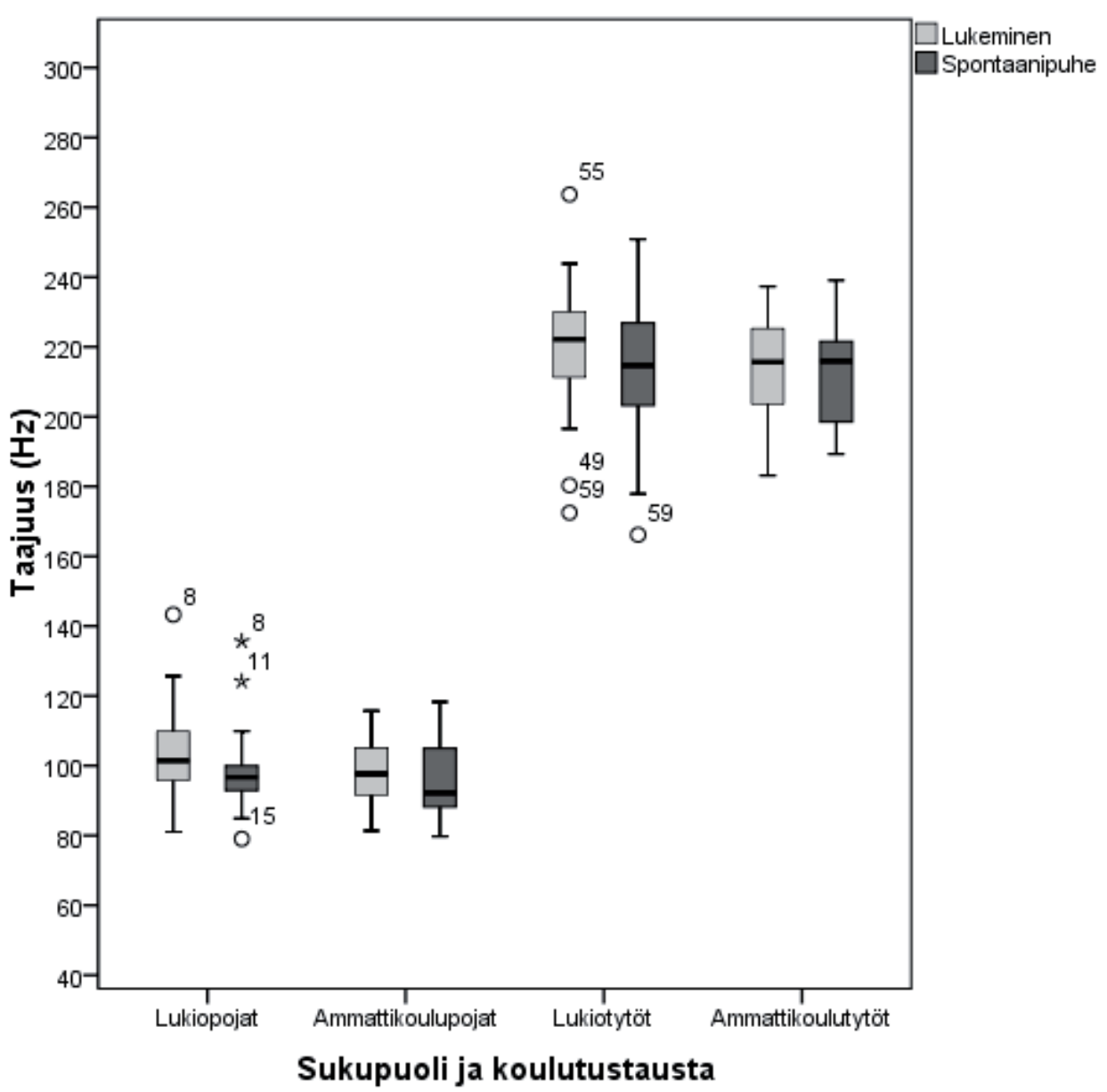

KUVIO 1. Poikien ja tyttöjen puheäänen korkeuden keskiarvo koulutustaustan mukaan eri puhetehtävissä. 
Lukiolaisten otoksissa esiintyi joitakin poikkeavia havaintoja, mutta kaikista otoksista ainoastaan lukiopojat eivät noudattaneet normaalijakaumaa. Osana testitilannetta koehenkilöitä myös pyydettiin ääntämään pidennetty vokaali /a/. Mitatut arvot näkyvät taulukossa 3 .

Johdonmukaista yhteyttä pidennetyn vokaalin tai puhenäytteiden F0:n väliltä ei löytynyt.

TAULUKKO 3. Pidennetty vokaali /a/.

\begin{tabular}{|l|c|c|}
\hline & $\overline{\mathrm{x}} \mathrm{FO}(\mathrm{Hz})$ & $\mathrm{SD}$ \\
\hline Lukiopojat & 101,7 & 15,4 \\
\hline Ammattikoulupojat & 94,1 & 10,3 \\
\hline Lukiotytöt & 219,6 & 21,1 \\
\hline Ammattikoulutytöt & 211,8 & 12,9 \\
\hline
\end{tabular}

\section{Sukupuolen, koulutustaustan sekä pubetilanteen ja tekstilajin vaikutus pubeen perustaajuuteen}

Sukupuoli tai koulutustausta ei erottanut otosten äänenkorkeuksien keskiarvoja minkään yksittäisen tekstin kohdalla, ja keskihajonta oli kaikissa puhetehtävissä lukiolaisilla suurempi kuin ammattikoululaisilla ja tytöillä suurempi kuin pojilla. Puhetilanne sen sijaan erotti otoksia: Kummatkin sukupuolet käyttivät luettaessa johdonmukaisesti hieman korkeampaa puheääntä kuin spontaanipuheessa (taulukko 4). Tytöillä ero oli tilastollisesti merkitsevä $(t=2.56, p=0,014)$, ja pojilla luennan ja spontaanipuheen välillä oli erittäin merkitsevä ero $(p<0,001)$. Vertailun vuoksi taulukkoon on merkitty sulkeisiin SallinenKuparisen (1985) tutkimuksen arvot.

TAULUKKO 4. Poikien ( $N=40)$ ja tyttöjen $(N=40)$ puheäänen korkeuden keskiarvo $\bar{x} F 0$ luennassa ja spontaanipuheessa. (Vuoden 1985 alkuperäistutkimuksen arvot kursiivilla suluissa, kummankin otoksen $\mathrm{N}=30$ )

\begin{tabular}{|c|c|c|c|c|c|c|c|}
\hline & \multicolumn{3}{|c|}{ Tytöt } & \multicolumn{4}{|c|}{ Pojat } \\
\hline & $\overline{\mathrm{X}} \mathrm{FO}(\mathrm{Hz})$ & SD & $t$ & $\overline{\mathrm{X}} \mathrm{FO}(\mathrm{Hz})$ & SD & W & $t$ \\
\hline Luenta & $\begin{array}{l}216 \\
(208)\end{array}$ & $\begin{array}{l}18,3 \\
(12,6)\end{array}$ & \multirow{2}{*}{$\begin{array}{l}2,6 * \\
(6,65 * * *)\end{array}$} & $\begin{array}{l}101 \\
(139)\end{array}$ & $\begin{array}{l}12,1 \\
(10,6)\end{array}$ & \multirow{2}{*}{$\begin{array}{l}p= \\
0,000 * * *\end{array}$} & \multirow{2}{*}{$(-0,84$ n.s. $)$} \\
\hline $\begin{array}{l}\text { Spontaani- } \\
\text { puhe }\end{array}$ & $\begin{array}{l}213 \\
(201)\end{array}$ & $\begin{array}{l}17,4 \\
(14,6)\end{array}$ & & $97(140)$ & $\begin{array}{l}11,9 \\
(11,7)\end{array}$ & & \\
\hline
\end{tabular}

$* p<0,05$

*** $p<0,001$ 
Kuten alkuperäistutkimuksessa lukunäytteiden tekstilaji oli myös tässä tutkimuksessa yhteydessä puhekorkeuteen: mitä muodollisempi teksti oli sisältönsä puolesta, sitä matalampaa F0 käytettiin. Vastaavasti F0 nousi lineaarisesti sisällön tunnepitoisuuden myötä (ks. esim. Costanzo, Markel \& Costanzo, 1969; Fairbanks \& Pronovost, 1939; Titze, 1989; Waaramaa, 2009). Tekstilajien välistä F0-eroa ei kuitenkaan testattu tässä tutkimuksessa tilastollisesti. Tutkimustilanteessa tutkittavien eläytyminen eri tekstilajeihin oli hillittyä.

Spontaanipuhenäytteissä tutkittavien suoriutumista verrattiin kuvasta kertomisen ja avoimeen kysymykseen vastaamisen avulla. F0:n keskiarvoissa ei havaittu tilastollisesti merkitsevää eroa yksilöittäin tai otoksittain. Tehtävätyyppien välillä oli kuitenkin havait- tavissa ero lauseintonaatiossa: sarjakuvasta kerrottaessa kuvien perättäisyys piti yllä nousevaa lauseintonaatiota, joka muuttui laskevaksi vasta viimeisessä kuvassa. Spontaanipuheessa lauseintonaatio oli pääosin laskeva. Ero lauseintonaatiossa ei silti vaikuttanut äänenkorkeuden keskiarvoon.

\section{Lukunopeus}

Lukutehtävissä koehenkilöiltä mitattiin lukemiseen käytettyä aikaa. Tekstit olivat merkkimäärältään hieman eripituisia, minkä vuoksi niiden välistä lukunopeutta ei voi verrata suoraan keskenään. Sen sijaan lukemisessa suoriutumista voi verrata otosten välillä kunkin tekstin sisällä. Taulukko 5 esittää lukemiseen käytetyn ajan sekä kussakin lukunäytteessä erikseen että yhteenlaskettuna.

TAULUKKO 5. Tekstien 1-3 lukunopeus sekunneissa. Ammattikoululaisilla $N=20$, lukiolaisilla $\mathrm{N}=19$.

\begin{tabular}{|c|c|c|c|c|c|c|c|c|c|c|}
\hline & Teksti 1 & $t$ & U & Teksti 2 & $t$ & Teksti 3 & $\mathrm{t}$ & Kaikki & $t$ & U \\
\hline Lukiopojat & 88,5 & \multirow{2}{*}{\multicolumn{2}{|c|}{$-2,66^{*}$}} & 79.4 & \multirow{2}{*}{$-1,89$} & 69,9 & \multirow{2}{*}{$-1,33$} & 79,3 & \multirow{2}{*}{\multicolumn{2}{|c|}{$-2,11^{*}$}} \\
\hline Amm.pojat & 97,75 & & & 85,2 & & 73,25 & & 85,4 & & \\
\hline Lukiotytöt & 85,65 & \multirow{2}{*}{\multicolumn{2}{|c|}{$\begin{array}{l}p= \\
0,168\end{array}$}} & 76,35 & \multirow{2}{*}{$\cdot 1,64$} & 69 & \multirow{2}{*}{$-1,541$} & 77,0 & \multirow{2}{*}{\multicolumn{2}{|c|}{$\begin{array}{l}p= \\
0,065\end{array}$}} \\
\hline Amm.tytöt & 87,45 & & & 78,45 & & 70,3 & & 78,7 & & \\
\hline
\end{tabular}

* $p<0,05$

Ääneen luettavat tekstit 1-3: uutinen (146 sanaa), mielipidekirjoitus (155 sanaa), satu (164 sanaa).

Kun lasketaan keskiarvo kaikista kolmesta tekstistä, ammattikoulupojat lukivat lukiopoikia hitaammin $\left(\mathrm{t}=-2,11^{*}, \mathrm{p}=0,042\right)$. Ammattikoulupojat käyttivät lukemiseen lukiopoikia enemmän aikaa jokaisessa tekstissä, mutta ero oli tilastollisesti merkitsevä vain tekstin 1 (uutinen) lukunopeudessa $(\mathrm{t}=$ $\left.-2,66^{*}, \mathrm{p}=0,012\right)$.

Lukunopeuteen vaikutti tekstien kielellinen vaikeustaso: vaikealukuisin teksti oli uu- tinen, joka edusti tyyliltään asiatekstiä ja jossa oli erikoissanastoa, ja helppolukuisin teksti oli satu, jossa sanasto oli helppoa ja sanapituus oli lyhyempi kuin muissa teksteissä. Tarkasteltaessa lukemiseen käytettyä aikaa eri teksteissä koulutustaustan mukaan havaitaan, että erotus kielellisesti haastavimman ja helpoimman tekstin välillä oli pojilla paljon suurempi kuin tytöillä. Toisin sanoen tyttöjen lukunopeus ei ollut sidoksissa koulutustaustaan tai teksti- 
lajiin; sen sijaan ammattikoulupojilla suoriutuminen hidastui kielellisen haasteen myötä suhteellisesti enemmän kuin lukiopojilla.

Lukiopoikien ja lukiotyttöjen otoskoko oli poikkeuksellisesti 19, sillä yksi koehenkilö kummastakin otoksesta oli yli 2 SD:n päässä muista. Kun poikkeavat havainnot eliminoitiin aineistosta, noudatti poikien aineisto normaalijakaumaa. Tyttöjen aineisto noudatti normaalijakaumaa lukunäytteissä 2 ja 3, mutta ei lukunäytteessä 1 eikä laskettaessa kaikki lukunäytteet yhteen.

\section{Ä̈̈nenkorkeuden itsearviointi}

Testitilanteen lopuksi koehenkilöitä pyydettiin merkitsemään $100 \mathrm{~mm}: n$ mittaiselle VAS-janalle, kuinka korkea puheääni heillä oli omasta mielestään. Taulukosta 6 ilmenee, että tutkittavat arvioivat puheäänensä kaikissa otoksissa keskiarvoista matalammaksi $(37,8 \mathrm{~mm})$ ja pojat arvioivat äänensä matalammaksi (35,3 mm) kuin tytöt (40,3 mm).

TAULUKKO 6. Arvio oman puheäänen korkeudesta 100 mm:n VAS-janalla

("Ääneni on mielestäni erittäin matala - erittäin korkea").

\begin{tabular}{|l|c|c|}
\hline & $\mathrm{mm}$ & $\mathrm{t}$ \\
\hline Lukiopojat & 29,7 & \multirow{2}{*}{$\cdot 2.5^{*}$} \\
\cline { 1 - 2 } Ammattikoulupojat & 40,9 & \\
\hline Pojat yhteensä & $\mathbf{3 5 , 3}$ & \\
\hline Lukiotytöt & 41,5 & \multirow{2}{*}{.49 n.s. } \\
\cline { 1 - 2 } Ammattikoulutytöt & 39,1 & \\
\cline { 1 - 2 } Tytöt yhteensä & $\mathbf{4 0 , 3}$ & \\
\cline { 1 - 2 } Kaikki yhteensä & $\mathbf{3 7 , 8}$ & \\
\hline
\end{tabular}

$* p<.05$

Lukiopojat arvioivat oman puheäänensä merkitsevästi matalammaksi kuin ammattikoulupojat $(\mathrm{t}=-2,5, \mathrm{p}=0,016)$. Kaikista 80 tutkittavasta 62 sijoitti itsensä VAS-janan vasempaan puoliskoon $(77,5 \%)$, kaksi vastaajaa sijoitti itsensä tasan puoliväliin (2,5\%), ja ainoastaan 16 vastausta $(20 \%)$ oli VAS-janan oikeassa puoliskossa. Tyttöjen vastauksissa vaihteluväli oli $14-73 \mathrm{~mm}$, ja $68 \%$ vastaajista arvioi äänensä välille $25-50 \mathrm{~mm}$; pojilla vaihteluväli oli $12-75 \mathrm{~mm}$, ja $63 \%$ vastaajista arvioi äänensä välille 25-50 mm.

Luennasta ja spontaanipuheesta mitattujen F0-arvojen sekä itsearvioiden välillä havaittiin positiivinen korrelaatio $(\mathrm{r}=0,292, \mathrm{p}<$ $0,01)$. Tytöillä korrelaatio oli tilastollisesti merkitsevä ja vahvempi kuin pojilla ( $\mathrm{r}=$
0,340, $\mathrm{p}=0,032)$. Pojilla havaittu positiivinen korrelaatio ei aivan yltänyt tilastolliseen merkitsevyyteen $(\mathrm{r}=0,301, \mathrm{p}=0,059)$.

\section{POHDINTA}

Tutkimuksen tulokset poikkesivat monelta osin alkuperäistutkimuksen tuloksista. Koulutustausta ei enää erottanut otoksia missään yksittäisessä puhetehtävässä, kun taas Sallinen-Kuparinen $(1985,1990)$ löysi koulutustaustaan liittyvän tilastollisesti merkitsevän eron tekstien lukunopeudessa ja tyttöjen F0:ssa. Nyt koulutustausta oli erottava tekijä ainoastaan poikien lukunopeudessa: ammattikoulupojat lukivat tilastollisesti merkitsevästi hitaammin kuin lukiopojat. Myös 
alkuperäistutkimuksessa ammattikoululaiset lukivat hitaammin kuin lukiolaiset, mutta lukunopeutta ei eritelty sukupuolten välillä.

Alkuperäistutkimuksessa havaittiin eroja puheäänen käytössä myös sukupuolten välillä. Aikaisemmin on myös todettu, että äänen piirteiden hyödyntäminen voi olla keino viestiä tietyn ryhmän, esimerkiksi nuorison, ammattiryhmän tai ideologisen yhteisön, yhteenkuuluvaisuutta (Scherer \& Giles, 1979). Nyt molemmilla sukupuolilla oli samanlaiset äänenkäyttötavat kaikissa puhetehtävissä. Koska tutkimusasetelma oli vastaava kuin alkuperäistutkimuksessa, tulosten perusteella näyttää siltä, että suomalaisnuorten puhekäyttäytymisessä on tapahtunut muutoksia 30 vuodessa. Puhekorkeuden käyttöä ovat voineet yhtenäistää sukupuolten välillä useat taustatekijät. Aiemmin koulutustausta on todennäköisesti vaikuttanut voimakkaammin nuorten identiteettiin, koska peruskouluuudistuksesta oli kulunut vasta lyhyt aika (Tarinoita yhtenäisestä perusopetuksesta, 2007). Tutkimusten välillä asenteet lukiota ja ammattikoulua kohtaan ovat voineet muuttua, jolloin mahdollinen poikien F0:n käyttöä rajoittava sosiaalinen normi on vapautunut. Toisaalta naisten rooli yhteiskunnassa on oletettavasti muuttunut 30 vuodessa jonkin verran, mikä puolestaan saattoi ilmetä tyttöjen tulosten muutoksessa: ero koulutustaustassa ei enää kuulunut heidän puhekorkeudessaan.

Puhetilanne vaikutti äänenkorkeuteen niin, että F0 oli luettaessa hieman korkeampi kuin spontaanipuheessa sekä tytöillä että pojilla. Tutkimuksen tulokset vahvistivat yleistä tutkimushavaintoa siitä, että ääneen luettaessa F0 on korkeampi kuin spontaanipuheessa (mm. Guimarães \& Abberton, 2005; Hollien \& Jackson, 1973; Murry ym. 1995). Alkuperäistutkimuksessa poikien tulos oli poikkeava, koska puhetilanne ei vaikuttanut merkitsevästi F0:an. Nyt sen sijaan poikien F0:ssa oli luonnollisempaa vaihtelua lukemisen ja spon- taanipuheen välillä ja myös eri tekstilajien välillä. Muutos on ääniergonomisesta näkökulmasta myönteinen, koska ääneen luonnollista käyttöä rajoittava normi saattaa johtaa liian korkealta tai matalalta puhumiseen, mikä lisää tarpeettomasti äänihuulien biomekaanista rasitusta. Poikien puheäänen käytössä näyttäisi siis tapahtuneen muutos verrattuna Sallinen-Kuparisen (1985) tuloksiin.

Syksyllä 2015 mitatut poikien taajuusarvot ovat huomattavasti matalampia kuin alkuperäistutkimuksessa, ja kansainvälisestikin verrattuna ne ovat matalat (ks. taulukko 1 esim. Andreeva ym., 2014; Hollien \& Jackson, 1973; Majewski ym., 1972; Natour \& Wingate, 2008; Pegoraro-Krook \& Castro, 1994). Suomalaispoikien F0-arvot ovat myös matalammat verrattuna ruotsia, englantia tai saksaa puhuvaan verrokkiaineistoon, joissa suositaan matalaa puhekorkeutta (esim. Andreeva ym., 2014, Britto \& Doyle, 1990; Ma \& Love, 2010, Pegoraro-Krook, 1988). On kuitenkin huomattava, että edellä mainituissa tutkimuksissa ikäjakauma oli 17 vuodesta ylöspäin, joten mukana oli vanhempia tutkittavia. Yksi mahdollinen selittävä tekijä poikien F0-eroon voikin olla ikä: uusintatutkimuksessa tutkittavat olivat pääosin 17-vuotiaita, kun taas alkuperäistutkimuksessa valtaosa oli ilmeisesti 16-vuotiaita. Ikäero ei kuitenkaan erottanut tutkittavia uusintatutkimuksessa, jossa kaikkien 16 vuotiaiden poikien $(n=5)$ F0 oli otoksen keskiarvon, noin $100 \mathrm{~Hz}$ tuntumassa.

Toinen selittävä tekijä voi olla median vaikutus: matalaa ääntä suositaan televisiossa ja radiossa, ja matalia tajuuksia korostetaan jopa keinotekoisesti (Kimittävä ääni madaltui vakuuttavaksi, 2011; Valo, 1994). Kolmanneksi on muistettava, että alkuperäinen mittauslaitteisto ei enää ollut käytettävissä uusintatutkimukseen, vaan tutkimuksissa käytettiin eri mittareita. Olettaen, että kummankin tutkimuksen mitatut arvot pitävät paikkansa, voidaan todeta 16-17-vuotiaiden 
suomalaispoikien F0:n laskeneen. Johtopäätösten tekemistä vaikeuttaa se, ettei tästä ikäryhmästä ole olemassa Sallinen-Kuparisen tulosten lisäksi juurikaan muuta vertailuaineistoa. Kun F0-arvoja vertaa toiseen suomalaisaineistoon (Leino ym., 2008), havaitaan, että 16-17-vuotiaiden poikien puhekorkeus (101 $\mathrm{Hz}$ ) on matala myös verrattuna 23-26-vuotiaisiin miehiin $(110 \mathrm{~Hz})$. On mahdollista, että poikien matala puhekorkeus liittyy täysiikäistymiseen: toisen asteen oppilaitoksessa on sosiaalisesti arvostettavampaa puhua matalalta ja korostaa miehistä ääntä kuin puhua keskirekisteristä, kuten yliopisto-opiskelijat. Täysi-ikäisyyden kynnyksellä olevien poikien F0:a saattaa siis muokata sosiaalinen normi, joka ei liitykään koulutustaustaan vaan koskee koko ikäluokkaa. Poikien käyttäytymismalli tuntuu loogiselta Ohalan (1994) äänisymbolismia vasten elämänvaiheessa, jossa murrosiän loppuvaiheissa vartalon koko on muuttunut, ja lapsen heleä ja korkea ääni on jäänyt taakse. Näin myös mahdollisesti äänenkorkeudella halutaan korostaa uusia miehisiä piirteitä, kun elämässä on entistä enemmän itsenäisyyttä, ja parinmuodostus on alkamassa.

Uusintatutkimuksessa jäljiteltiin alkuperäistutkimuksen asetelmaa mahdollisimman tarkasti, jotta tulokset keskustelisivat keskenään ja tutkimusten välille syntyisi aikajatkumo. Vaikka uusintatutkimuksessa oli mahdollista mukailla alkuperäistutkimuksen asetelmaa (Sallinen-Kuparinen, 1990) melko yksityiskohtaisesti, alkuperäisten tekstien asemesta käytettiin funktioltaan vastaavia ja nykypäivän oppilaalle tutumpia tekstejä (Ketolainen, 2016). Alkuperäistä mittalaitteistoa ei ollut mahdollista käyttää, koska sitä ei ole enää olemassa. Tämän vuoksi tulosten numeeriset arvot eivät ole keskenään suoraan vertailukelpoisia, mutta tuloksia on mahdollista verrata ilmiötasolla.

Poikien eroon lukunopeudessa vaikutti koulutustausta mutta myös itse tekstit.
Vaikka lukihäiriön vaikutus seulottiin pois esitietolomakkeessa, ammattikoululaiset käyttivät lukemiseen lukiolaisia enemmän aikaa kaikissa teksteissä. Myös koehenkilöitä rekrytoitaessa havaittiin, että ammattikoulussa lukihäiriö esiintyi poissulkukriteerinä useammin kuin lukiossa. Lukemisen ja kirjoittamisen vaikeudella onkin todettu olevan yhteys alhaisempaan koulutustasoon aikuisena (Boetsch, Green \& Pennigton, 1996; Finucci, Gottfredson \& Childs, 1985; Hagell \& Maughan, 1996; Lavikainen ym., 2006; Undheim, 2002) ja henkilöt, joilla on todettu lukivaikeus, hankkivat itselleen pääsääntöisesti toisen asteen ammatillisen koulutuksen (Boetsch ym., 1996).

VAS-janan avulla tehty itsearvio toi lisätietoa suomalaisnuorten subjektiivisesta kokemuksesta omasta äänenkorkeudestaan. Mielenkiintoista oli, että puheääni arvioitiin keskimääräistä matalammaksi kaikissa otoksissa. Tutkittavat suosivat mielikuvaa keskiverrosta tai jonkin verran matalammasta puheäänestä. Toisaalta he välttivät äärimmäisiä arvoja: vastausten vaihteluväli oli $12-75 \mathrm{~mm}$. Tutkittavat varoivat erityisesti määrittelemästä omaa ääntä korkeaksi. On mahdollista, että vastaamista ohjasivat osittain kulttuuriset mielikuvat hyvästä puheäänestä. Suomalaisten mielestä miellyttävän kuuloinen puheääni on matala, sävelkorkeudeltaan vaihteleva ja persoonallinen; liian matalaa tai korkeaa sekä laadultaan möreää tai kimakkaa ääntä pidetään huonona (Valo, 1994). Koska sekä tyttöjen että poikien itsearviot korreloivat ääninäytteiden puheäänen korkeuden kanssa, VAS-janaa voi pitää ainakin suuntaa antavana mittarina äänenkorkeuden itsearvioinnissa.

Mistä kertoo sitten se, että lukiopojat arvioivat puheäänensä merkitsevästi matalammaksi kuin ammattikoulupojat? Lukiopoikien F0 ei ollut merkitsevästi ammattikoulupoikia korkeampi, mutta kenties poikien sosiaalinen status on erilainen lukiossa ja ammattikoulussa. 
Liioitteleva itsearvio saattoi ilmentää tiedostamatonta vakuuttavuuden tavoittelua tai toiveajattelua maskuliinisemmasta äänestä, sillä matala puheääni on Suomessa sosiokulttuurisesti suosittu ominaisuus - eräänlainen normi, josta korkea puheääni on poikkeus (Valo, 1994). Äänenkorkeuteen voi siis liittyä tiedostamattomia sosiaalisia paineita, jotka näyttäisivät koskevan erityisesti lukiopoikia. Tämän tutkimuksen otoskoon vuoksi havaintoa ei voi yleistää koko populaatioon, mutta tulokset voivat antaa viitteitä eri koulutustaustojen sosiaalisista rakenne-eroista.

\section{LOPUKSI}

Tämä tutkimus esittää tuoretta tietoa suomea äidinkielenään puhuvien 16-17-vuotiaiden nuorten puheäänen korkeudesta. Tulosten mukaan koulutustausta ei enää normita oppilaiden ääni-identiteettiä yhtä vahvasti kuin 30 vuotta sitten (Sallinen-Kuparinen, 1985), vaan suomalaisnuoret puhuvat samalla lailla kävivätpä he ammattikoulua tai lukiota. Sekä tytöt että pojat suosivat keskiarvoista matalampaa ääntä itsearviossa, ja pojat näyttäisivät käyttävän matalampaa puheääntä kuin 1980-luvulla. Havainto on mielenkiintoinen logopedisesta näkökulmasta, sillä puheen perustaajuus on suoraan yhteydessä äänentuoton kuormittavuuteen. Ääniergonomisesti on suositeltavaa tavoitella puhujalle luontevinta, optimaalista puhekorkeutta, joka sijoittuu modaalirekisterin keskivaiheille ja on puheentuottoelimistölle tarkoituksenmukaista. Tällöin puheentuotto on yleensä fysiologisesti vaivattominta ja taloudellisinta, koska mahdollisimman vähällä työllä saadaan mahdollisimman hyvä resonanssi (Laukkanen \& Leino, 1999). Tutkimuksemme perusteella erityisesti tyttöjen osalta puheäänen korkeutta säätelevissä normeissa vaikuttaisi tapahtuneen myönteistä vapautumista luonnollisem- man äänenkäytön suuntaan. Pojat puolestaan varioivat äänenkorkeuttaan luonnollisemmin eri puhetehtävien välillä kuin alkuperäistutkimuksessa, mutta matalan puheäänen käyttö voi olla ääniergonomisesti rasittavaa.

Aihetta olisi jatkossa kiinnostava tutkia isommalla otoskoolla. 16-17-vuotiaiden puheäänen korkeudesta olisi perusteltua tehdä normitus, sillä vastikään murrosiän ylittäneiden nuorten puheääni on ollut tutkimuksellisesti katveessa. Aiempi tutkimus alkaa olla vanhentunutta, ja tutkimustieto tai viiteaineisto tästä ikäryhmästä on myös kansainvälisesti vähäistä. Emme toistaiseksi tiedä alueellisen ja sosiaalisen vaihtelun vaikutuksesta F0:an Suomessa, minkä vuoksi aineistoa olisi tärkeä kerätä eri puolilta maata - maaseudulta ja kaupungeista, sekä tytöiltä että pojilta. Jatkotutkimuksessa voisi myös selvittää muita nuorten puheessa esiintyviä piirteitä tai niihin liittyviä stereotypioita, kuten esimerkiksi narinan esiintymistä maaseudulla ja kaupungissa varttuneiden nuorten puheessa, tai verrata kantaväestöön kuuluvien nuorten F0:a monikielisten tai maahanmuuttajataustaisten nuorten F0:an.

Puheäänen korkeus välittää tietoa puhujan sukupuolesta, iästä ja terveydentilasta, mutta sekundaaristi siitä voidaan päätellä jotain puhujan taustalla vaikuttavista kulttuurisista ja sosiaalisista rakenteista, puhujan yksilöllisestä tavasta käyttää ääntä sekä siitä, millaisen kuvan puhuja haluaa välittää itsestänsä muille. Erilaisten sosiokulttuuristen ja behavioraalisten taustatekijöiden ilmeneminen puheäänessä on yleensä tiedostamatonta, ja ne voivat johtaa epäoptimaaliselta korkeudelta puhumiseen ja äärimmillään jopa äänihäiriöihin. Tämän vuoksi puheterapeutin on kliinisessä työssä tärkeä olla tietoinen edellä mainittujen taustatekijöiden vaikutuksesta äänenkäyttöön. 


\section{LÄHTEET}

Andreeva, B., Demenko, G., Möbius, B., Zimmerer, F., Jügler, J. \& Oleskowicz-Popiel, M. (2014). Differences of pitch profiles in germanic and slavic languages. Teoksessa Proceedings of Interspeech 2014 (Singapore), 1307-1311.

Aronson, A. E. (1973). Psychogenetic voice disorders: Audioseminars in speech pathology. Philadelphia, PA: Saunde

Avery, J. D. \& Liss, J. M. (1996). Acoustic characteristics of less-masculine sounding male speech. Journal of the Acoustical Society of America, 99, 3738-3748.

Bless, D. M., Glaze, L. E., Biever-Lowery, D., Campos, G. \& Peppard, R. C. (1993). Stroboscopic, acoustic, aerodynamic, and perceptual attributes of voice production in normal speaking adults. Teoksessa I. R. Titze (toim.), Progress Report 4(s. 121-134). Iowa City, IA: National Center for Voice and Speech.

Boersma, P. \& Weenink, D. (2015). Praat: Doing phonetics by computer, versio 5.4.18. Haettu 10.9.2015 osoitteesta http://www.praat.org/

Boetsch, E. A., Green, P. A. \& Pennigton, B. F. (1996). Psychosocial correlates of dyslexia across the life span. Development and Psychopathology, 8, 539-562.

Boone, D. R. (1991). Is your voice telling on you? Lontoo: Whurr.

Brend, R. M. (1975). Male-female intonation patterns in American English. Teoksessa B. Thorne \& N. Henley (toim.), Language and sex: Difference and dominance (s. 84-87). Rowley, MA: Newbury House.

Britto, A. I. \& Doyle, P. C. (1990). A comparison of habitual and derived optimal voice fundamental frequency values in normal young adult speakers. Journal of Speech and Hearing Disorders, 55, 476-484.

Brodnitz, F. S. (1965). Vocal rehabilitation. Rochester, MN: American Academy of Ophthalmology and Otolaryngology.

Brown, W. S., Morris, R. J., Hollien, H. \& Howell, E. (1991). Speaking fundamental frequency characteristics as a function of age and professional singing. Journal of Voice, 5, 310-315.

Chevrie-Muller, C., Salomon, D. \& Ferrey, G. (1971). Contribution a l'établissement de quelques constantes physiologiques de la voix parlée de la femme adolescente, adulte et age. Journal Français d'Oto-Rhino-Laryngologie, XVI, 433-455.

Consensus auditory-perceptual evaluation of voice (CAPE-V). Special interest division 3 , voice and voice disorders, (2006). Haettu 30.11.2016 osoitteesta http://www.asha.org.

Cooper, M. (1973). Modern techniques of vocal rehabilitation. Springfield, IL: Charles C. Thomas.

Cooper, M. (1984). Change yourvoice, change your life. New York: Macmillan.

Costanzo, F. S., Markel, N. N. \& Costanzo, P. R. (1969). Voice quality profile and perceived emotion. Journal of Counseling Psychology, 16, 267-270.

da Silva, P. T., Master, S., Andreoni, S., Pontes, P. \& Ramos, L. R. (2011). Acoustic and long-term average spectrum measures to detect vocal aging in women. Journal of Voice, 25, 411-419.

Dolson, M. (1994). The pitch of speech as a function of linguistic community. Music Perception, 11, 321-331.

Elert, C-C. (1977). Universella och kulturberoende orsaker till könsskillnader i språket. Teoksessa K. Nordin \& M. Thelander (toim.), Könsrolleri språk, FUMS rapport 49 (s. 17-19). Uppsala.

Fairbanks, G. \& Pronovost, W. (1939). An experimental study of the pitch characteristics of the voice during the expression of emotion. Speech Monographs, 6, 87-104.

Fichtelius, A., Johansson, I. \& Nordin, K. (1980). Three investigations of sex-associated speech variation in day school. Women's Studies International Quarterly, 3, 219-225.

Finucci, J. M., Gottfredson, L. S. \& Childs, B. (1985). A follow-up study of dyslexic boys. Annals of Dyslexia, 35, 117-136.

Fitch, J. L. \& Holbrook, A. (1970) Modal fundamental frequency of young adults. Archives of Otolaryngology, 92, 379-382.

Gilmore, S. I., Guidera, A. M, Hutchins, S. L. \& van Steenbrugge, W. (1992). Intra-subject variability and the effect of speech task on vocal fundamental frequency of young adult Australian males and females. Australian Journal of Human Communication Disorders, 20, 65-73.

Guimarães, I. \& Abberton, E. (2005). Fundamental frequency in speakers of Portuguese 
for different voice samples. Journal of Voice, 19, 592-606.

Hagell, A. \& Maughan, B. (1996). Poor readers in adulthood: Psychosocial functioning. Development and Psychopathology, 8, 457-476.

Hollien, H. \& Jackson, B. (1973). Normative data on the speaking fundamental frequency characteristics of young adult males. Journal of Phonetics, $1,117-120$.

Hollien, H. \& Ship, T. (1972). Speaking fundamental frequency and chronological age in males. Journal of Speech, Language, and Hearing Research, 15, 155-159.

IBM Corp. Released 2010. IBM SPSS Statistics for Macintosh, Versio 19.0. Armonk, NY: IBM Corp.

Jiang, J. J. \& Titze, I. R. (1994). Measurement of vocal fold intraglottal pressure and impact stress. Journal of Voice, 8, 132-144.

Jones, B. C., Feinberg, D. R., DeBruine, L. M., Little, A. C. \& Vukovic, J. (2010). A domainspecific opposite-sex bias in human preferences for manipulated voice pitch. Animal Behaviour, 79, 57-62.

Kempster, G. B., Gerratt, B. R., Verdolini Abbott, K., Barkmeier-Kramer, J. \& Hillman, R. E. (2009). Consensus auditory-perceptual evaluation of voice: Development of a standardized clinical protocol. American Journal of SpeechLanguage Pathology, 18, 124-132.

Ketolainen, I. (2016). Puheäänen korkeus 16-17-vuotiailla suomalaisilla nuorilla. Pro gradu -tutkielma. Turun yliopisto. Yhteiskuntatieteellinen tiedekunta. Psykologian ja logopedian laitos.

Kimittäväääni madaltuivakuuttavaksi,2011. Haettu 10.12.2016 osoitteesta http://yle.fi/uutiset/ kimittava_aani_madaltui_vakuuttavaksi/ 5329657

Kitzing, P. (1979). Glottografisk frekvensindikering: En undersökningsmetod för mätning av röstläge och röstomfäng samt framställning av röstfrekvensdistributionen. Malmö: Lund University.

Lakoff, R. (1973). Language and woman's place. Language in Society, 2, 45-80.

Lass, N. J., Hughes, K. R., Bowyer, M. D., Waters, L. T. \& Bourne, V. T. (1976). Speaker sex identification from voiced, whispered, and filtered isolated vowels. Journal of the Acoustical Society of America, 59, 675-678.
Laukkanen, A-M. \& Leino, T. (1999). Ibmeellinen ibmisääni: Ä̈̈nenkäytön ja pubetekniikan perusteet, arviointi, mittaaminen ja kehittäminen. Helsinki: Gaudeamus.

Lavikainen, H., Koskinen, S., Aro, H., Kestilä, L., Lyytinen, H., Martelin, T., Pensola, T., Rahkonen, O. \& Aromaa, A., (2006). Kouluterveyden yleisyys ja yhteydet aikuisiän elämäntilanteeseen ja koettuun terveyteen. Yhteiskuntapolitiikka, $71,402-410$.

Lee, A., Hewlett, N. \& Nairn, M. (1995). Voice and gender in children. Teoksessa S. Mills (toim.), Language and gender: Interdisciplinary perspectives (s. 194-204). Lontoo ja New York: Longman.

Leino, T., Laukkanen, A-M., Ilomäki, I. \& Mäki, E. (2008). Assessment of vocal capacity of Finnish university students. Folia Phoniatrica et Logopaedica, 60, 199-209.

Leino, T., Laukkanen, A-M., Kättö, R., Mäki, E. \& Ilomäki, I. (1998). Average fundamental frequency of Finnish female students in the 1970's and in the 1990's. Proceedings 24th IALP Congress (Amsterdam), vol. 1, 60-62.

Ma, E. P-M. \& Love, A. L. (2010). Electroglottographic evaluation of age and gender effects during sustained phonation and connected speech. Journal of Voice, 24, 146-152.

Majewski, W., Hollien, H. \& Zalewski, J. (1972). Speaking fundamental frequency of Polish adult males. Phonetica, 25, 119-125.

Martin, F., Klingholz, F. \& Eicher, W. (2012). Perception of pitch location within a speaker's range: Fundamental frequency, voice quality and speaker sex. Journal of the Acoustical Society of America, 132, 1100-1112.

Muranaka, C. (1996, 13. kesäkuuta) Women newscasters lowering pitch. The Daily Yomiuri. Murry, T., Brown, W. S. \& Morris, R. J. (1995). Patterns of fundamental frequency for three types of voice samples. Journal of Voice, 3, 282289.

Natour, Y. S. \& Wingate, J. M. (2008). Fundamental frequency characteristics of Jordanian Arabic speakers. Journal of Voice, 23, 560-566.

Neumann, K. \& Welzel, C. (2003). The importance of the voice in male-to-female transsexualism. Journal of Voice, 18, 153-167.

Ohala, J. J. (1994). The frequency code underlies the sound-symbolic use of voice pitch. Teokses- 
sa L. Hinton, J. Nichols, \& J. J. Ohala (toim.), Sound symbolism (s. 325-347). Cambridge: Cambridge University Press.

Ohara, Y. (1992). Gender dependent pitch levels: A comparative study in Japanese and English. Teoksessa K. Hall., M. Bucholtz \& B. Moonwomon (toim.), Locating power. Proceedings of the second Berkeley women and language conference, vol. 2, 468-477.

Okamoto, S. (1995). “Tasteless” Japanese: Less "feminine" speech among young Japanese women. Teoksessa K. Hall \& M. Bucholtz (toim.), Gender articulated: Language and the socially constructed self (s. 297-325). New York: Routledge.

Pegoraro-Krook, M. I. (1988). Speaking fundamental frequency characteristics of normal Swedish subjects obtained by glottal frequency analysis. Folia Phoniatrica et Logopaedica, 40, 82-90.

Pegoraro-Krook, M. I. \& Castro, V. C. (1994). Normative speaking fundamental frequency (SFF) characteristics of Brazilian male subjects. Brazilian Journal of Medical and Biological Research, 27, 1659-1661.

Pemberton, C., McCormack, P. \& Russell, A. (1998). Have women's voices lowered across time? A cross sectional study of Australian women's voices. Journal of Voice, 12, 208-213.

Plexico, L. W. \& Sandage, M. J. (2017). Influence of glottal fry on acoustic voice assessment: A preliminary study. Journal of Voice, 31, 378. e13-378.e17.

Rousey, C. L. \& Moriarty, A. E. (1965). Diagnostic implications of speech sounds: The reflections of developmental conflict and trauma. Springfield, IL: Charles C. Thomas.

Sachs, J., Lieberman, P. \& Erikson, D. (1973). Anatomical and cultural determinants of male and female speech. Teoksessa R. W. Shuy \& R. W. Fasold (toim.), Language attitudes: Current trends and prospects (s. 74-84). Washington D.C.: Georgetown University Press.

Sallinen-Kuparinen, A. (1985). Pitch level and type of oral task. Teoksessa P. Hurme (toim.), Pubeentutkimuksen alalta, 6 (s. 79-92). Jyväskylän yliopiston viestintätieteiden laitoksen julkaisuja. Jyväskylä: Jyväskylän yliopisto.

Sallinen-Kuparinen, A. (1990). Kronografia. Kerronnan ja luennan aika-akselin instrumentaa- lista, perkeptuaalista ja lingvististä analyysia. Jyväskylän yliopiston viestintätieteiden laitoksen julkaisuja 7. Jyväskylä: Jyväskylän yliopisto.

Scherer, K. R. \& Giles, H. (toim.) (1979). Social markers in speech. Cambridge: Cambridge University Press.

Seikel J. A., King D. W. \& Drumright D. G. (2005). Anatomy and physiology for speech, language and hearing (3. painos). Clifton Park, NY: Thomson Delmar Learning.

Simpson, A. P. (2009). Phonetic differences between male and female speech. Language and Linguistics Compass, 3, 621-640.

Stemple, J. C., Glaze, L. E. \& Klaben, B. (2010). Clinical voice pathology: Theory and management (4. painos). San Diego, CA: Plural Publishing Inc.

Stoicheff, M. L. (1981) Speaking fundamental frequency of middle-aged females. Folia Phoniatrica, 19, 167-172.

Tarinoita yhtenäisestä perusopetuksesta, 2007. Haettu 10.12.2016 osoitteesta http://www. oph.fi/julkaisut/2007/tarinoita_yhtenaisesta _perusopetuksesta

Titze, I. R. (1989). On the relation between subglottal pressure and fundamental frequency in phonation. Journal of the Acoustical Society of America, 85, 901-906.

Tuomi, S. K. \& Fisher, J. E. (1979). Characteristics of simulated sexy voice. Folia Phoniatrica et Logopaedica, 31, 242-249.

Undheim, A. M. (2002). Dyslexia and psychosocial factors. A follow-up study of youngNorwegian adults with a history of dyslexia in childhood. Nordic Journal of Psychiatry, 57, 221-226.

Valo, M. (1994). Käsityksetja vaikutelmat äänestä: Kuuntelijoiden arviointia radiopubeen äänellisistä ominaisuuksista. Väitöskirja. Jyväskylän yliopisto. Studia Philologica Jyväskyläensia 33. van Bezooijen, R. (1995). Sociocultural aspects of pitch differences between Japanese and Dutch women. Language and Speech, 38, 253-265

van Borsel, J., Janssens, J. \& de Bodt, M. (2009). Breathiness as a feminine voice characteristic: A perceptual approach. Journal of Voice, 23, 291-294.

van Riper, C. (1972). Speech correction: Principles and methods. Englewood Cliffs: Prentice Hall. 
Waaramaa, T. (2009). Emootiot puheäänessä. Teoksessa O. Aaltonen, R. Aulanko, A. Iivonen, A. Klippi \& M. Vainio (toim.), Pubuva ibminen (s. 191-197). Keuruu: Kustannusosakeyhtiö Otava.

Welch, G. F. \& Howard, D. M. (2002). Gendered voice in the cathedral choir. Psychology of Music, 30, 102-120.

Wewers, M. E. \& Lowe, N. K. (1990). A critical review of visual analogue scales in the measurement of clinical phenomena. Research in Nursing and Health, 13, 227-236.
White, P. (1999). Formant frequency analysis of children's spoken and sung vowels using sweeping fundamental frequency production. Journal of Voice, 13, 570-582.

Yamazawa, H. \& Hollien, H. (1992) Speaking fundamental frequency patterns of Japanese women. Phonetica, 49, 128-140.

\section{PITCH LEVEL OF 16-17-YEAR-OLD FINNISH STUDENTS IN READING AND SPONTANEOUS SPEECH TASKS}

Ilkka Ketolainen, University of Turku, Department of Psychology and Speech-Language Pathology Minna Laakso, University of Turku, Department of Psychology and Speech-Language Pathology Susanna Simberg, Åbo Akademi University, Faculty of Arts, Psychology and Theology, University of Oslo, Faculty of Educational Sciences

Fundamental frequency (F0) in speech is mainly defined by anatomical and biological factors, but it is also affected by different socio-cultural and behavioral models of voice usage. Unoptimal voice usage models can lead to voice disorders. This research examined the F0 of 16-17-year-old Finnish native speakers in reading and in spontaneous speech. In addition, the F0 in a sustained vowel as well as the reading speed was measured, and the students were asked to evaluate their own F0 on a VAS scale. The results were compared with Aino Sallinen-Kuparinen's (1985) study, which stated that the speakers' educational background and sex influence their F0.

The speaking behaviour of Finnish students seems to have changed during the past 30 years: in the original study, girls attending a vocational school used a higher F0 than girls attending a high school. In addition, the speakers' sex contributed to some differences in the students' speaking behaviour. In the present study, neither the educational background nor the speaker's sex had an effect on the pitch level. The girls' F0 was $216 \mathrm{~Hz}$ in reading and $213 \mathrm{~Hz}$ in spontaneous speech. The boys had a low F0 compared to international studies: $101 \mathrm{~Hz}$ in reading and $97 \mathrm{~Hz}$ in spontaneous speech. Possibly the boys in this age are affected by a social norm, which values a low speaking fundamental frequency. Low F0 was preferred also in the self-evaluation: the majority of the test persons estimated their own F0 to be lower than average.

Keywords: F0, social norms, voice 